\title{
Evaluation of the Blood Level of Adiponectin in Pregnant Adolescents
}

\section{Avaliação dos níveis séricos de adiponectina em gestantes adolescentes}

\author{
Elaine Cristina Rocha Pádua ${ }^{10}$ Silvia Daher ${ }^{1}{ }^{(1)}$ Isa de Pádua Cintra Sampaio ${ }^{20}$ \\ Edward Araujo Júnior ${ }^{1(1)}$ Cristina Falbo Guazzelli ${ }^{10}$ \\ 1 Department of Obstetrics, Escola Paulista de Medicina, Universidade \\ Federal de São Paulo, São Paulo-SP, Brazil \\ 2 Department of Pediatrics, Escola Paulista de Medicina, Universidade \\ Federal de São Paulo, São Paulo-SP, Brazil \\ Address for correspondence Edward Araujo Júnior, Rua Napoleão de \\ Barros, 875, 04024-002,Vila Clementino, São Paulo, SP Brazil \\ (e-mail: araujojred@terra.com.br).
}

Rev Bras Ginecol Obstet 2021;43(6):429-435.

\begin{abstract}
Objective To evaluate serum levels of adiponectin in pregnant adolescents between 30 and 36 weeks of gestation.

Method: A prospective cross-sectional study enrolled 67 normal pregnant women between 30 and 36 weeks of gestation and eutrophic (body mass index [BMI]: $18.5-25 \mathrm{~kg} / \mathrm{m}^{2}$ ), of which 36 were adolescents ( $<20$ years old) and 31 adults ( $\geq$ 20 years old). Serum adiponectin levels were determined by enzyme-linked immunosorbent assay (ELISA). The $t$-student or Mann-Whitney tests were used for intergroup comparison.

Results Pregnant adolescents showed significantly higher serum adiponectin concentrations compared with pregnant adults $(p=0.04)$. No differences were observed in adiponectin levels in younger pregnant adolescents ( $<16$ years old) compared with older pregnant adolescents ( $\geq 16$ years old). Adiponectin values were divided into 3 subgroups: $<3,000 \mathrm{ng} / \mathrm{mL}$, between 3,000 and $5,000 \mathrm{ng} / \mathrm{mL}$, and $>5,000 \mathrm{ng} / \mathrm{mL}$. Birthweight was significantly higher in women $>5,000 \mathrm{ng} / \mathrm{mL}$ when compared with $<3,000 \mathrm{ng} / \mathrm{mL}$ in the adolescent group. No association between pregestational

Keywords

- adiponectin

- adolescence

- gestation

- inflammation adiponectin levels and BMI, gestational weight gain, and gestational age was observed; however, there was a positive relation with birthweight $(p=0.0239)$.

Conclusion Serum adiponectin values in pregnant adolescents between 30 and 36 weeks of gestation were higher compared with pregnant adults; however, no differences between younger and older pregnant adolescents were observed.
\end{abstract}

received

March 24, 2020

accepted

February 18, 2021

published online

June 2, 2021
DOI https://doi.org/

10.1055/s-0041-1730288.

ISSN $0100-7203$. (c) 2021. Federação Brasileira de Ginecologia e Obstetrícia. All rights reserved.

This is an open access article published by Thieme under the terms of the Creative Commons Attribution License, permitting unrestricted use, distribution, and reproduction so long as the original work is properly cited. (https://creativecommons.org/licenses/by/4.0/)

Thieme Revinter Publicações Ltda., Rua do Matoso 170, Rio de Janeiro, RJ, CEP 20270-135, Brazil 


\section{Resumo}

\section{Palavras-chave \\ - adiponectina \\ - adolescência \\ - gestação \\ - inflamação}

Objetivo Avaliar os níveis séricos de adiponectina em gestantes adolescentes entre 30 e 36 semanas de gestação.

Métodos Estudo prospectivo e transversal incluindo 67 gestantes normais entre 30 a 36 semanas e eutróficas (índice de massa corporal [IMC]: $18,5-25 \mathrm{~kg} / \mathrm{m}^{2}$ ), sendo 36 adolescentes ( $<20$ anos) e 31 adultas ( $\geq 20$ anos). Os níveis séricos de adiponectina foram avaliados por teste imunoenzimático (ELISA, na sigla em inglês). Para a comparação entre os grupos, utilizou-se os testes t-Student ou Mann-Whitney.

Resultados As gestantes adolescentes apresentaram significativamente maiores concentrações séricas de adiponectina do que as adultas $(p=0,04)$. Não houve diferenças nos níveis de adiponectina quando comparadas as gestantes adolescentes precoces ( $<16$ anos) às tardias ( $\geq 16$ anos). Os valores de adiponectina foram subdivididos em 3 grupos: $<3.000 \mathrm{ng} / \mathrm{mL}$, entre 3.000 e $5.000 \mathrm{ng} / \mathrm{mL}$ e $>5.000 \mathrm{ng} / \mathrm{mL}$. $\mathrm{O}$ peso do recém-nascido foi significantemente maior nas mulheres com $>5.000$ $\mathrm{ng} / \mathrm{mL}$, quando comparadas as com $<3.000 \mathrm{ng} / \mathrm{mL}$ no grupo das adolescentes. Não foi observada associação entre os níveis de adiponectina e o IMC pré-gestacional, ganho de peso gestacional e a idade gestacional, porém houve relação positiva com o peso do recém-nascido $(p=0,0239)$.

Conclusão Os valores séricos de adiponectina em gestantes adolescentes entre $30 \mathrm{e}$ 36 semanas de gestação foram maiores do que os das gestantes adultas; contudo, sem diferenças entre gestantes adolescentes precoces e tardias.

\section{Introduction}

Adiponectin is a polypeptide hormone abundantly produced and secreted by adipose tissue that regulates metabolism by interfering in insulin resistance in hepatic and cellular territories. ${ }^{1}$ It stimulates glucose uptake by adipocytes and myocytes and directly activates adenosine monophosphate activated protein kinase (AMPK), acting as an insulin sensitizer. The main metabolic effects of adiponectin include glucose and lipid metabolism regulation through fatty acid oxidation stimulation, suppression of hepatic glucose production, and increased insulin sensitivity in liver and muscle tissue. ${ }^{2,3}$ In contrast to other hormones secreted by the adipose tissue, its serum level decreases as adiposity increases and are negatively correlated with obesity, insulin resistance, and metabolic syndrome. ${ }^{1,4}$ Furthermore, it presents other roles, presenting antihyperglycemic, antiatherogenic and anti-inflammatory properties. ${ }^{5,6}$

Adiponectin is produced abundantly by adipose tissue and circulates at high concentration, in contrast to other adipokines. Although it is secreted by adipocytes, plasma adiponectin concentration is paradoxically lower in patients with type 2 diabetes mellitus, cardiovascular diseases, obesity, and in smokers. ${ }^{7}$ Weight reduction in obese individuals is accompanied by an increase in plasma adiponectin concentration, suggesting that adipose tissue can exert a negative feedback on adiponectin production and secretion. ${ }^{8,9}$

Serum adiponectin levels differ according to gender, being higher in women compared with men, even after matching for weight and body mass index (BMI). ${ }^{10}$ In adolescents, no change in serum adiponectin concentration is observed between genders. However, studies showed that adiponectin levels, similar to what is observed in adults, are lower in obese adolescents and in pubescents. These values relate negatively to age and are significantly lower in puberty compared with the prepuberal period. Puberty is associated with decreased insulin sensitivity and changes in serum adiponectin concentrations. ${ }^{11,12}$

Age effects in adiponectin production is still controversial, but many studies could observe differences in adiponectin levels between ages. It seems that adiponectin levels increase with advancing age, ${ }^{13-17}$ and an experimental study indicated that estrogens have the ability to inhibit adiponectin production. ${ }^{18}$ There are still few studies about adiponectin and puberty, but Lausten-Thomsen et al. ${ }^{19}$ showed that, in adolescent women, adiponectin levels increase with increasing age and demonstrated how age- and sex-specific reference curves for adipokines are still necessary.

During pregnancy, there is a hypothesis that adiponectin may also play an important role in insulin resistance. ${ }^{20}$ Lower concentrations of adiponectin have been consistently reported in patients with gestational diabetes mellitus (GDM) when compared with patients with a healthy pregnancy. ${ }^{21,22}$

Since adiponectin has an essential role in insulin metabolism and that glucose and insulin are crucial for fetal growth, maternal adiponectin may play an important role in fetal development; however, the literature results about this association are still controversial. ${ }^{23-25}$

The aim of the present study was to evaluate serum adiponectin concentration in pregnant adolescents between 30 and 36 weeks of gestation. 


\section{Methods}

A prospective cross-sectional study was conducted with eutrophic (BMI between 18.5 and $25 \mathrm{~kg} / \mathrm{m}^{2}$ ) pregnant adolescents ( $<20$ years old) and adults ( $\geq 20$ years old), between 30 and 36 weeks of gestation. The subjects were selected from the Ambulatory of Prenatal Physiology of the Department of Obstetrics of Universidade Federal de São Paulo (UNIFESP, in the Portuguese acronym). The exclusion criteria were multiple pregnancies or chronic maternal diseases, such as arterial hypertension, pregestational diabetes mellitus or systemic lupus erythematosus. The present study was approved by UNIFESP's Ethics Committee ( $n^{\circ} 1714 / 10$ ), and all subjects signed the informed consent form.

A blood sample of $8 \mathrm{~mL}$ was drawn by venipuncture from the pregnant subject in a sterile and dry tube with separation gel (BD Diagnostics, Franklin Lakes, NJ, USA). The sample collected was centrifuged after clot retraction, and the obtained serum was aliquoted and stored in sterile microtube in a freezer at $-80^{\circ}$ C. Serum adiponectin levels were determined by enzyme-linked immunosorbent assay (ELISA) capture method using Quantikine-Human Adiponectin/Acrp30 DuoSet (R\&D [R\&D Systems Inc., Minneapolis, MN, USA]) commercial kit. This is an immunoenzymatic assay based on the sandwich technique performed according to the instructions of the manufacturer. Adiponectin sensitivity was $62.5 \mathrm{pg} / \mathrm{mL}$.

Descriptive statistics with mean, median, minimum and maximum values and standard deviation (SD) was performed for all quantitative variables, and frequency analysis was performed for qualitative variables. The Kolmogorov-Smirnov or Shapiro-Wilk tests and Skewness and Kurtosis values were used to evaluate distribution for quantitative variables. Intergroup comparisons of quantitative variables were made using the $t$-Student test when distribution was normal and the Mann-Whitney test when distribution was non-normal.

Factorial analysis of variance (ANOVA) was used to compare the means of categorical variables by adiponectin concentration $(\mathrm{ng} / \mathrm{mL})$ and gestational group (adolescents and adults). When significant differences were observed by $F$ statistic, the post-hoc Fisher LSD test was used to determine those differences.

Linear regression analysis was used to assess the association between adiponectin concentration and the other independent variables, with a 95\% confidence interval (CI). Comparisons between adolescent and adult regressions were made using the $t$-Student test, and in the presence of significant differences, regression analyses were performed to define the better adjustment of curves.

To determine the influence of the variables study group, age, race, BMI, systolic and diastolic blood pressures, gestational age, pregnancy numbers, and birthweight on adiponectin concentration, a Stepwise Forward linear regression analysis was performed. Intergroup comparisons of qualitative variables were made using the chi-squared test, Fischer exact tests or G-tests.

The analyses were performed using GraphPad Prism 5.0 statistical package (GraphPad Software, San Diego, CA, USA). A statistical significance of $p<0.05$ was adopted.

\section{Results}

A total of 143 pregnant adolescents were followed-up, and blood samples were collected from 60 of them. In accordance with the exclusion criteria, 24 pregnant subjects were excluded, and, therefore, 36 were included ( - Fig. 1). Thirtyone pregnant adults were selected, all with the same gestational period, absence of chronic maternal diseases and within the same BMI interval.

The age for pregnant adolescents varied from 13 to 19 years old, average of 16.53 years old, whereas in adults the age varied from 20 to 38 years old, average of 28.06 years old. Regarding marital status, the majority of the adolescents was single $(63.9 \%)$, whereas adults were married $(35.5 \%)$ or in a stable union (41.9\%). - Table 1 presents the sociodemographic characteristics of the study population.

In relation to the number of pregnancies and parturition, there was a significant intergroup difference, with fewer pregnancies $(p<0.0001)$ and lower numbers of children $(p<0.0001)$ in adolescents compared with adults. When we assessed gestational age at the time of collection and birthweight, no significant difference was observed between both groups (- Table $\mathbf{1}$ ). Serum adiponectin concentrations were significantly higher in pregnant adolescents compared with adults $(p=0.04)$ ( - Fig. 2 ).

In the younger adolescent group ( $<16$ years old), the age varied from 13 to 15 years old, with an average of 14.25 years old. In turn, in the older adolescent group ( $\geq 16$ years old), the average age was 17.67 years old, varying from 16 to 19 years old. Older adolescents had more years of study (10.96 years) compared with the younger group ( 8.83 years). Regarding race, marital status and salaried work, there was no difference between groups (- Table 2).

Serum adiponectin concentrations showed no significant differences in both pregnant adolescent subgroups $(p=0.57)$. We categorized adiponectin levels in 3 groups: $<3,000 \mathrm{ng} / \mathrm{mL}$, between $3,000 \mathrm{ng} / \mathrm{mL}$ and $5,000-$ $\mathrm{ng} / \mathrm{mL}$, and $>5,000 \mathrm{ng} / \mathrm{mL}$; and evaluated the intergroup

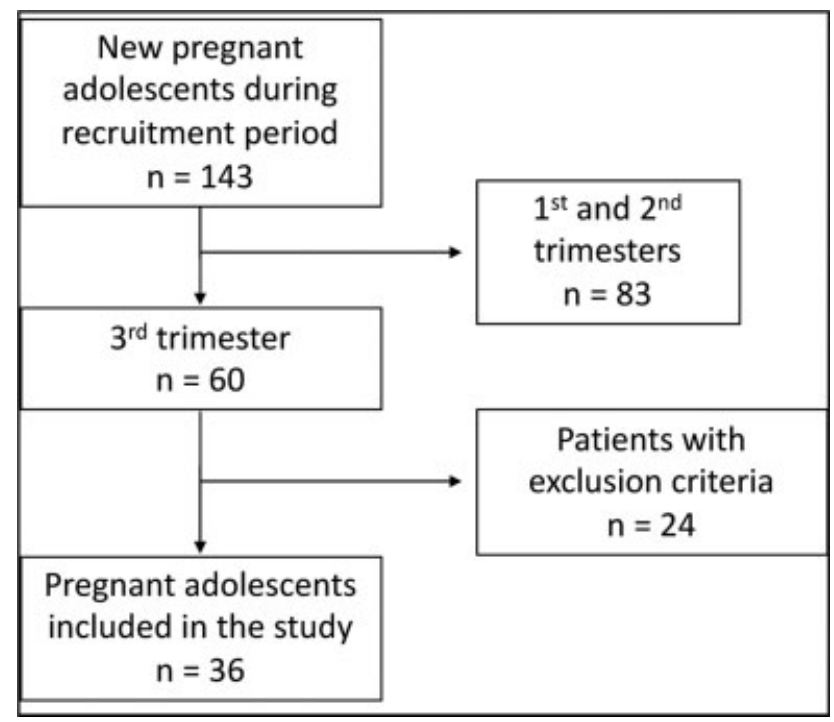

Fig. 1 Flow chart of the selection of pregnant adolescents. 
432 Evaluation of the Blood Level of Adiponectin in Pregnant Adolescents Pádua et al.

Table 1 Sociodemographic, obstetric and perinatal characteristics of pregnant adolescents and adults

\begin{tabular}{|c|c|c|c|}
\hline Variable & $\begin{array}{l}\text { Adolescents } \\
n=36\end{array}$ & $\begin{array}{l}\text { Adults } \\
n=31\end{array}$ & p-value \\
\hline Age (years old) ${ }^{\mathrm{a}}$ & $16.53(1.98)$ & 28.06 (4.99) & $<0.0001^{*}$ \\
\hline Race $^{b}$ & & & $0.19^{* *}$ \\
\hline White & $13(36.1 \%)$ & $13(41.9 \%)$ & \\
\hline Multiracial & $15(41.7 \%)$ & $16(51.6 \%)$ & \\
\hline Black & $8(22.2 \%)$ & $2(6.5 \%)$ & \\
\hline Marital status ${ }^{\mathrm{b}}$ & & & $0.003^{* *}$ \\
\hline Single & $23(63.9 \%)$ & $6(19.4 \%)$ & \\
\hline Married & $5(13.9 \%)$ & $11(35.5 \%)$ & \\
\hline Stable union & $8(22.2 \%)$ & $13(41.9 \%)$ & \\
\hline Divorced & $0(0 \%)$ & $1(3.2 \%)$ & \\
\hline $\begin{array}{l}\text { Years of study } \\
\text { (years) }^{\mathrm{a}}\end{array}$ & $10.25(1,96)$ & $10.89(2,13)$ & $0.22^{*}$ \\
\hline Salaried work ${ }^{\mathrm{b}}$ & & & $<0.0001^{\dagger}$ \\
\hline Yes & $8(22.2 \%)$ & $22(71.0 \%)$ & \\
\hline No & $28(77.8 \%)$ & $9(29.0 \%)$ & \\
\hline Smoking ${ }^{\mathrm{b}}$ & & & $0.02^{\dagger}$ \\
\hline Yes & $1(2.8 \%)$ & 7 (22.6\%) & \\
\hline No & $35(97.2 \%)$ & $24(78.4 \%)$ & \\
\hline Alcohol abuse ${ }^{b}$ & & & $0.002^{\dagger}$ \\
\hline Yes & $1(2.8 \%)$ & $10(32.3 \%)$ & \\
\hline No & $35(97.2 \%)$ & $21(67.7 \%)$ & \\
\hline BMI $\left(\mathrm{Kg} / \mathrm{m}^{2}\right)^{\mathrm{a}}$ & $21.59(2.20)$ & $21.25(1.62)$ & $0.48^{*}$ \\
\hline $\begin{array}{l}\text { GA at collection } \\
\text { (weeks) }^{\text {a }}\end{array}$ & $32.45(1.58)$ & $33.19(1.51)$ & $0.055^{*}$ \\
\hline $\begin{array}{l}\text { Number of } \\
\text { pregnancies }^{b}\end{array}$ & & & $<0.0001^{\dagger}$ \\
\hline 1 & $35(97.2 \%)$ & $11(35.5 \%)$ & \\
\hline$\geq 2$ & $1(2.8 \%)$ & $20(64.5 \%)$ & \\
\hline Parturition $^{\mathrm{b}}$ & & & $<0.0001^{* *}$ \\
\hline 0 & $35(97.2 \%)$ & $14(45.2 \%)$ & \\
\hline 1 & $1(2.8 \%)$ & $12(38.7 \%)$ & \\
\hline$\geq 2$ & $0(0 \%)$ & $5(16.1 \%)$ & \\
\hline Birthweight (grams) ${ }^{a}$ & $3103(570.5)$ & $3065(245.0)$ & $0.72^{\S}$ \\
\hline
\end{tabular}

Abbreviations: BMI, body mass index; GA, gestational age.

${ }^{a}$ mean (standard deviation).

babsolute number (percentage).

${ }^{*} t$-Student Test.

${ }^{* *}$ Chi-squared Test.

${ }^{\dagger}$ Fisher Test.

$\S$ Welch adjusted $t$-Student Test.

difference and association with the independent variables. Factorial ANOVA was used to compare means ( \pm SD) of categorical variables by adiponectin concentration $(\mathrm{ng} / \mathrm{mL})$ and gestational group (adolescents and adults). When significant differences were observed by F statistic, the post-hoc Fisher LSD test was used to determine those differences. It was possible to observe that adiponectin categories were

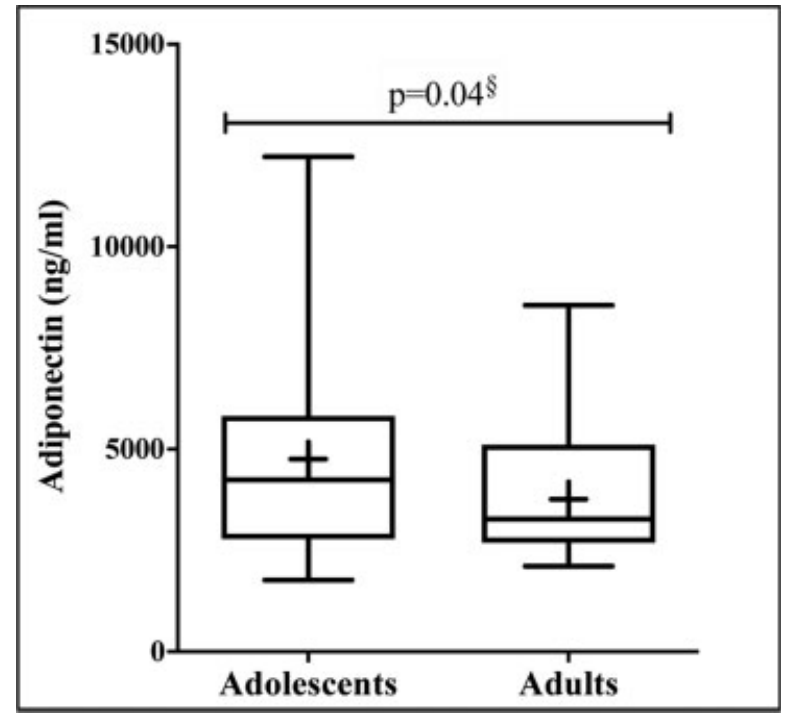

Fig. 2 Serum adiponectin levels in pregnant adolescents $(n=36)$ and adults $(n=31)$

${ }^{\S}$ Welch's adjusted $t$-Student Test.

Table 2 Sociodemographic characteristics of younger and older adolescents

\begin{tabular}{|c|c|c|c|}
\hline Variable & $\begin{array}{l}\text { Adolescents } \\
<16 \\
n=12\end{array}$ & $\begin{array}{l}\text { Adolescents } \\
\geq 16 \\
n=24\end{array}$ & p-value \\
\hline Age (years old) ${ }^{a}$ & $14.25(0.75)$ & $17.67(1.27)$ & $<0.0001^{*}$ \\
\hline Race $^{b}$ & & & $0.82^{* *}$ \\
\hline White & $5(41.7 \%)$ & $8(33.3 \%)$ & \\
\hline Multiracial & 5 (41.7\%) & $10(41.7 \%)$ & \\
\hline Black & $2(16.6 \%)$ & $6(25.0 \%)$ & \\
\hline Marital status $^{\mathrm{b}}$ & & & $0.13^{* *}$ \\
\hline Single & $6(50.0 \%)$ & 17 (70.8\%) & \\
\hline Married & 1 (8.3\%) & $4(16.7 \%)$ & \\
\hline Stable union & $5(41.7 \%)$ & $3(12.5 \%)$ & \\
\hline $\begin{array}{l}\text { Years of study } \\
\text { (years) a }^{\text {a }}\end{array}$ & $8.83(1.40)$ & $10.96(1.83)$ & $0.001^{*}$ \\
\hline Salaried work ${ }^{\mathrm{b}}$ & & & $0.22^{\dagger}$ \\
\hline Yes & $\begin{array}{l}11(91.7 \%) \\
1(8.3 \%)\end{array}$ & $\begin{array}{l}17(70.8 \%) \\
7(29.2 \%)\end{array}$ & \\
\hline \multicolumn{4}{|l|}{ No } \\
\hline Smoking ${ }^{b}$ & & & $0.33^{\dagger}$ \\
\hline Yes & 1 (8.3\%) & $0(0 \%)$ & \\
\hline No & $11(91.7 \%)$ & $24(100 \%)$ & \\
\hline Alcohol abuse ${ }^{b}$ & & & $1.00^{\dagger}$ \\
\hline Yes & $0(0 \%)$ & 1 (4.2\%) & \\
\hline No & $12(100 \%)$ & $23(95.8 \%)$ & \\
\hline $\operatorname{BMI}\left(\mathrm{Kg} / \mathrm{m}^{2}\right)^{a}$ & 20.95 (1.97) & $21.91(2.28)$ & $0.22^{*}$ \\
\hline
\end{tabular}

Abbreviation: BMI, body mass index.

${ }^{a}$ mean (standard deviation).

babsolute number (percentage).

*t-Student Test.

${ }^{* *}$ Chi-square Test.

†Fisher Test. 
Table 3 Influence of independent variables on adiponectin concentration (ng/mL) according to pregnancy group

\begin{tabular}{|c|c|c|c|c|c|c|c|c|c|}
\hline & \multicolumn{3}{|c|}{ Adolescents } & \multicolumn{3}{|l|}{ Adults } & \multicolumn{3}{|l|}{ Statistic F } \\
\hline & $\begin{array}{l}<3,000 \\
(n=10)\end{array}$ & $\begin{array}{l}3,000-5,000 \\
(n=12)\end{array}$ & $\begin{array}{l}>5,000 \\
(n=14)\end{array}$ & $\begin{array}{l}<3,000 \\
(n=12)\end{array}$ & $\begin{array}{l}3,000-5000 \\
(n=11)\end{array}$ & $\begin{array}{l}>5,000 \\
(n=8)\end{array}$ & $\begin{array}{l}\mathrm{F}_{(1,66)} \\
\text { p-value }\end{array}$ & $\begin{array}{l}\mathrm{F}_{(2,66)} \\
\text { p-value }\end{array}$ & $\begin{array}{l}\mathrm{F}_{(2,66)} \\
\text { p-value }\end{array}$ \\
\hline $\begin{array}{l}\text { Gestational } \\
\text { age (days) }\end{array}$ & $\begin{array}{l}224.20 \\
(11.16)\end{array}$ & $\begin{array}{l}230.50 \\
(11.67)\end{array}$ & $\begin{array}{l}226.43 \\
(10.54)\end{array}$ & $\begin{array}{l}230.83 \\
(9.76)\end{array}$ & $\begin{array}{l}233.91 \\
(14.09)\end{array}$ & $\begin{array}{l}230.63 \\
(9.16)\end{array}$ & $2.91 ; 0.09$ & $1.08 ; 0.34$ & $0.12 ; 0.88$ \\
\hline $\begin{array}{l}\text { Weight } \\
\text { gain }(\mathrm{kg})\end{array}$ & $\begin{array}{l}13.45 \\
(4.42)\end{array}$ & $\begin{array}{l}13.47 \\
(4.69)\end{array}$ & $\begin{array}{l}13.34 \\
(5.02)\end{array}$ & $\begin{array}{l}10.85 \\
(4.66)\end{array}$ & $\begin{array}{l}10.47 \\
(4.30)\end{array}$ & $\begin{array}{l}11.94 \\
(4.28)\end{array}$ & $4.15 ; 0.05$ & $0.12 ; 0.89$ & $0.17 ; 0.84$ \\
\hline BMI $\left(\mathrm{kg} / \mathrm{m}^{2}\right)$ & $\begin{array}{l}21.26 \\
(1.68)\end{array}$ & $\begin{array}{l}21.53 \\
(2.66)\end{array}$ & $\begin{array}{l}21.89 \\
(2.21)\end{array}$ & $\begin{array}{l}20.83 \\
(1.75)\end{array}$ & $\begin{array}{l}21.16 \\
(1.26)\end{array}$ & $\begin{array}{l}22.00 \\
(1.81)\end{array}$ & $0.22 ; 0.64$ & $1.12 ; 0.33$ & $0.12 ; 0.89$ \\
\hline SBP ( & $\begin{array}{l}104.00 \\
(13.50)\end{array}$ & $\begin{array}{l}105.83 \\
(14.43)\end{array}$ & $\begin{array}{l}107.14 \\
(9.14)\end{array}$ & $\begin{array}{l}90.00 \\
(11.28)\end{array}$ & $\begin{array}{l}102.73 \\
(11.04)^{\mathrm{a}, \S}\end{array}$ & $\begin{array}{l}95.00 \\
(10.69)^{\S}\end{array}$ & $11.17 ;<0.01$ & 0.13 & $1.38 ; 0.26$ \\
\hline $\mathrm{DBP}(\mathrm{mm} \mathrm{Hg})$ & $\begin{array}{l}65.00 \\
(10.80)\end{array}$ & $\begin{array}{l}70.00 \\
(11.28)\end{array}$ & $\begin{array}{l}69.29 \\
(11.41)\end{array}$ & $\begin{array}{l}54.17 \\
(9.00)^{\S}\end{array}$ & $\begin{array}{l}65.45 \\
(11.28)^{\mathrm{a}}\end{array}$ & $\begin{array}{l}58.75 \\
(12.46)^{\S}\end{array}$ & $10.00 ;<0.01$ & $3.06 ; 0.05$ & $0.58 ; 0.56$ \\
\hline $\begin{array}{l}\text { Birth } \\
\text { weight (g) }\end{array}$ & $\begin{array}{l}2828.00 \\
(564.88)\end{array}$ & $\begin{array}{l}3037.58 \\
(525.60)\end{array}$ & $\begin{array}{l}3355.71 \\
(539.18)^{\mathrm{a}}\end{array}$ & $\begin{array}{l}2950.83 \\
(210.00)\end{array}$ & $\begin{array}{l}3056.36 \\
(210.00)\end{array}$ & $\begin{array}{l}3248.13 \\
(310.11)\end{array}$ & $0.01 ; 0.91$ & $5.01 ; 0.01$ & $0.39 ; 0.68$ \\
\hline
\end{tabular}

Abbreviations: BMI, body mass index; DBP: diastolic blood pressure; SBP, systolic blood pressure.

${ }^{*}$ Adolescents and adults.

${ }^{* *}$ Categories of adiponectin concentration.

***Interaction between 'adolescents and adults' and 'categories of adiponectin concentration'.

a'Significant difference in adiponectin concentration $<3,000 \mathrm{ng} / \mathrm{mL}$.

§Significant difference for adolescents.

related to birth weight, regardless of the pregnancy group

(-Table 3).

The association of serum adiponectin levels with the independent variables (gestational age, weight gain, BMI, systolic and diastolic blood pressures, and birthweight) was also evaluated using univariate linear regression. A positive relation between adiponectin levels and birthweight was observed in all assessed pregnant subjects $(p=0.0239)$.

To determine the influence of variables on adiponectin concentration, a Stepwise Forward linear regression analysis was performed. In a first analysis of the main components that might influence adiponectin concentration in pregnant subjects, it was observed that some variables (race, pregnancy numbers, gestational age, and systolic and diastolic blood pressures) were not important to the model, considering the modification they produced together in the model $\left(\mathrm{R}^{2}\right.$ variation $\left.=0.31 \%\right)$, absence of statistical significance $\left(\mathrm{F}_{(9,57)}=1.56 ; p=0.15\right)$, and lack of model adjustment $\left(R^{2}=0.20 ; R_{\text {adjusted }}^{2} 0.07\right)$.

A second analysis was performed. When just the "birthweight" variable was included, it resulted in a model statistically significant $\left(\mathrm{F}_{(1,65)}=5.35 ; p=0.02\right)$, but with poor association $(R=0.28)$. When "Birth weight" and "Age" variables were included, it resulted in a statistically significant model $\left(\mathrm{F}_{(2,64)}=4.75 ; p=0.01\right)$, but with a weak association $(\mathrm{R}=0.36)$. Next, when the "birthweight," "age" and "group (adolescents and adults)" variables were included, it resulted in a statistically significant model $\left(\mathrm{F}_{(3,63)}=4.46 ; p=0.01\right)$, but still with weak association $(R=0.42)$. Then, when the "birthweight," "age," "group (adolescents and adults)" and "BMI" variables were included, it resulted in a model with moderate association $(\mathrm{R}=0.44)$, statistically significant $\left(\mathrm{F}_{(4,62)}=3.74 ; p=0.01\right)$, and with a better adjustment $\left(\mathrm{R}^{2}=0.20 ; \mathrm{R}^{2}\right.$ adjusted $\left.=0.15\right)$.

\section{Discussion}

In the present study, it was observed that pregnant adolescents showed higher serum adiponectin levels compared with pregnant adults. Rasmussen-Torvik et al. ${ }^{26}$ assessed serum adiponectin concentrations in male and female adolescents from 15 to 22 years old and observed higher levels in those with an average age of 15 years old compared with adolescents between 19 and 22 years old. In this study, the BMI was higher in older adolescents, from 19 to 22 years old, displaying greater abdominal circumference. Fifteen-yearold subjects showed a lower BMI, smaller abdominal circumference, and higher adiponectin concentration. The authors concluded that insulin sensitivity in younger adolescents was related to visceral fat, whereas adiponectin was associated with subcutaneous fat. ${ }^{26}$ Among adult women, serum adiponectin levels tend to decrease as weight increases, in relation to an increase in adiposity, causing BMI changes. ${ }^{16}$

Our results revealed higher adiponectin values in pregnant adolescents regardless of the age group. When younger adolescents ( $<16$ years old) were analyzed, no differences in serum adiponectin levels were observed when compared with older adolescents ( $\geq 16$ years old). Both groups were highly heterogeneous regarding social, clinical, and obstetric characteristics, but with no differences in adiponectin levels between them. A possible explanation would be the small number of younger adolescents, in which higher adiponectin levels are expected. All adolescents had already experienced their respective menarche, so despite of separating younger from older adolescents, the hormonal variations probably responsible for the changes in blood adiponectin levels were not so evident in these groups. 
Another important aspect of the present study was the racial balance between groups. Adiponectin values are strongly hereditary and are linked to genes that can be changed by race-dependent polymorphisms. Genetic load interferes with the prevalence of overweight or obesity in the studied population. ${ }^{27}$ A significant association was observed between adiponectin values and single nucleotide polymorphism of the gene coding this protein. These changes are observed mainly in white women, but not among black women, reinforcing the difference observed between races. $^{28}$

Another factor that could interfere in adiponectin concentration would be weight gain during pregnancy and, again, there was no association in our study. Some studies revealed a negative correlation between adiponectin and maternal BMI; ${ }^{29,30}$ however, in relation to our study, other studies did not attain the same results. ${ }^{31,32}$

Adipokines not only influence maternal metabolism during pregnancy but may also affect fetal growth. ${ }^{33}$ Our study showed a positive association between adiponectin levels and birthweight in all pregnant subjects evaluated. When the groups are studied separately, this association is demonstrated only in pregnant adolescents.

Pregnant adolescents with adiponectin levels $>5,000$ $\mathrm{ng} / \mathrm{mL}$ seem to give birth to more babies with adequate weight $(\sim 3,000 \mathrm{~g})$ compared with subjects with adiponectin values $<3,000 \mathrm{ng} / \mathrm{mL}$ that had insufficient average birthweight $(<3,000 \mathrm{~g})$. Our findings are similar to those observed by Mazaki-Tovi et al., ${ }^{34}$ who showed that maternal adiponectin levels are decreased when newborns present lower birthweight $(<2,999 \mathrm{~g})$, described as insufficient.

The exact mechanism of how maternal adiponectin levels can affect birthweight still deserves more investigation. While there are studies that did not find this association, ${ }^{25,35}$ other authors observed a negative association. ${ }^{36}$ However, our result corroborates with another recent study that showed a positive association between maternal adiponectin and birthweight. ${ }^{24}$ The association between maternal serum and umbilical cord adiponectin levels has been investigated, but the results are also conflicting. While some authors described an association between maternal and umbilical cord adiponectin, ${ }^{23}$ others observed the opposite. ${ }^{25}$ Aye et al. $^{37}$ proposed a mechanism by how adiponectin could affect birthweight, indicating that maternal adiponectin decreases placental insulin-signaling in the placenta, inhibiting fetal growth.

\section{Conclusion}

In summary, we observed that serum adiponectin values were higher in pregnant adolescents than in pregnant adults; however, with no differences between younger and older pregnant adolescents. In addition to that, a significant difference in birthweight was observed when the categories of serum adiponectin concentration $>5,000$ $\mathrm{ng} / \mathrm{mL}$ and $<3,000 \mathrm{ng} / \mathrm{mL}$ were compared in pregnant adolescents.

\section{Contributors}

All authors were involved in the design and interpretation of the analyses, contributed to the writing of the manuscript, read and approved the final manuscript.

\section{Conflict of Interests}

The authors have no conflict of interests to declare.

\section{References}

1 Catalano PM, Hoegh M, Minium J, Huston-Presley L, Bernard S, Kalhan S, et al. Adiponectin in human pregnancy: implications for regulation of glucose and lipid metabolism. Diabetologia. 2006;49 (07):1677-1685. Doi: 10.1007/s00125-006-0264-X

2 Scherer PE. Adipose tissue: from lipid storage compartment to endocrine organ. Diabetes. 2006;55(06):1537-1545. Doi: 10.2337/db06-0263

3 Hada Y, Yamauchi T, Waki H, Tsuschida A, Hara K, Yago H, et al. Selective purification and characterization of adiponectin multimer species from human plasma. Biochem Biophys Res Commun. 2007;356(02):487-493. Doi: 10.1016/j.bbrc.2007.03.004

4 Mazaki-Tovi S, Romero R, Vaisbuch E, Erez O, Mittal P, Chaiworapongsa $T$, et al. Maternal serum adiponectin multimers in gestational diabetes. J Perinat Med. 2009;37(06):637-650. Doi: 10.1515/JPM.2009.101

5 Mazaki-Tovi S, Romero R, Kusanovic JP, Erez O, Vaisbuch E, Gotsch F, et al. Adiponectin multimers in maternal plasma. J Matern Fetal Neonatal Med. 2008;21(11):796-815. Doi: 10.1080/14767050802266881

6 Low CF, Mohd Tohit ER, Chong PP, Idris F. Adiponectin SNP45TG is associated with gestational diabetes mellitus. Arch Gynecol Obstet. 2011;283(06):1255-1260. Doi: 10.1007/s00404-0101548-4

7 Zavalza-Gómez AB, Anaya-Prado R, Rincón-Sánchez AR, MoraMartínez JM. Adipokines and insulin resistance during pregnancy. Diabetes Res Clin Pract. 2008;80(01):8-15. Doi: 10.1016/j.diabres.2007.12.012

8 Gimeno RE, Klaman LD. Adipose tissue as an active endocrine organ: recent advances. Curr Opin Pharmacol. 2005;5(02): 122-128. Doi: 10.1016/j.coph.2005.01.006

9 Hutley L, Prins JB. Fat as an endocrine organ: relationship to the metabolic syndrome. Am J Med Sci. 2005;330(06):280-289. Doi: 10.1097/00000441-200512000-00005

10 Waki H, Yamauchi T, Kamon J, Ito Y, Uchida S, Kita S, et al. Impaired multimerization of human adiponectin mutants associated with diabetes. Molecular structure and multimer formation of adiponectin. J Biol Chem. 2003;278(41):40352-40363. Doi: 10.1074/ jbc.M300365200

11 Andersen KK, Frystyk J, Wolthers OD, Heuck C, Flyvbjerg A. Gender differences of oligomers and total adiponectin during puberty: a cross-sectional study of 859 Danish school children. J Clin Endocrinol Metab. 2007;92(05):1857-1862. Doi: 10.1210/ jc.2006-2310

12 Boney CM, Verma A, Tucker R, Vohr BR. Metabolic syndrome in childhood: association with birth weight, maternal obesity, and gestational diabetes mellitus. Pediatrics. 2005;115(03):e290-e296. Doi: 10.1542/peds.2004-1808

13 Staiger H, Tschritter O, Machann J, Thamer C, Fritsche A, Maerker E, et al. Relationship of serum adiponectin and leptin concentrations with body fat distribution in humans. Obes Res. 2003;11 (03):368-372. Doi: 10.1038/oby.2003.48

14 Cnop M, Havel PJ, Utzschneider KM, Carr DB, Sinha MK, Retzlaff BM, et al. Relationship of adiponectin to body fat distribution, insulin sensitivity and plasma lipoproteins: evidence for independent roles of age and sex. Diabetologia. 2003;46(04):459-469. Doi: $10.1007 / \mathrm{s} 00125-003-1074-\mathrm{z}$ 
15 Koh SJ, Hyun YJ, Choi SY, Chae JS, Kim JI Y, Sungha Park, et al. Influence of age and visceral fat area on plasma adiponectin concentrations in women with normal glucose tolerance. Clin Chim Acta. 2008;389(1-2):45-50. Doi: 10.1016/j.cca.2007.11.017

16 Lecke SB, Morsch DM, Spritzer PM. Leptin and adiponectin in the female life course. Braz J Med Biol Res. 2011;44(05):381-387

17 Mancuso P, Bouchard B. The impact of aging on adipose function and adipokine synthesis. Front Endocrinol (Lausanne). 2019; 10:137. Doi: 10.3389/fendo.2019.00137

18 Combs TP, Berg AH, Rajala MW, Klebanov S, Iyengar P, JimenezChillaron JC, et al. Sexual differentiation, pregnancy, calorie restriction, and aging affect the adipocyte-specific secretory protein adiponectin. Diabetes. 2003;52(02):268-276. Doi: 10.2337/diabetes.52.2.268

19 Lausten-Thomsen U, Lund MAV, Frithioff-Bøjsøe C, Hedley PL, Pedersen $\mathrm{O}$, Hansen $\mathrm{T}$, et al. Reference values for leptin/adiponectin ratio in healthy children and adolescents. Clin Chim Acta. 2019;493:123-128. Doi: 10.1016/j.cca.2019.03.004

20 Leung KC, Xu A, Craig ME, Martin A, Lam KS, O'Sullivan AJ. Adiponectin isoform distribution in women-relationship to female sex steroids and insulin sensitivity. Metabolism. 2009;58 (02):239-245. Doi: 10.1016/j.metabol.2008.09.020

21 Hara K, Yamauchi T, Kadowaki T. Adiponectin: an adipokine linking adipocytes and type 2 diabetes in humans. Curr Diab Rep. 2005;5(02):136-140. Doi: 10.1007/s11892-005-0041-0

22 Georgiou HM, Lappas M, Georgiou GM, Marita A, Bryant VJ, Hiscock R, et al. Screening for biomarkers predictive of gestational diabetes mellitus. Acta Diabetol. 2008;45(03):157-165. Doi: 10.1007/s00592-008-0037-8

23 Ballesteros M, Simón I, Vendrell J, Ceperuelo-Mallafré V, Miralles RM, Albaiges G, et al. Maternal and cord blood adiponectin multimeric forms in gestational diabetes mellitus: a prospective analysis. Diabetes Care. 2011;34(11):2418-2423. Doi: 10.2337/dc11-0788

24 Ma L, Lu Q Ouyang J, Huang J, Huang S, Jiao C, et al. How are maternal dietary patterns and maternal/fetal cytokines associated with birth weight? A path analysis. Br J Nutr. 2019;121(10): 1178-1187. Doi: 10.1017/S0007114519000382

25 Fazeli Daryasari SR, Tehranian N, Kazemnejad A, Razavinia F, Tork Tatari F, Pahlavan F. Adiponectin levels in maternal serum and umbilical cord blood at birth by mode of delivery: relationship to anthropometric measurements and fetal sex. BMC Pregnancy Childbirth. 2019;19(01):344. Doi: 10.1186/s12884-019-2460-y

26 Rasmussen-Torvik LJ, Pankow JS, Jacobs DR Jr, Steinberger J, Moran A, Sinaiko AR. Development of associations among central adiposity, adiponectin and insulin sensitivity from adolescence to young adulthood. Diabet Med. 2012;29(09):1153-1158. Doi: 10.1111/j.1464-5491.2012.03726.x
27 Rasmussen-Torvik LJ, Wassel CL, Ding J, Carr J, Cushman M, Jenny $\mathrm{N}$, et al. Associations of body mass index and insulin resistance with leptin, adiponectin, and the leptin-to-adiponectin ratio across ethnic groups: the Multi-Ethnic Study of Atherosclerosis (MESA). Ann Epidemiol. 2012;22(10):705-709. Doi: 10.1016/j. annepidem.2012.07.011

28 Cohen SS, Gammon MD, North KE, Milikan RC, Lange EM, Williams SM, et al. ADIPOQ, ADIPOR1, and ADIPOR2 polymorphisms in relation to serum adiponectin levels and BMI in black and white women. Obesity (Silver Spring). 2011;19(10):2053-2062. Doi: 10.1038/oby.2010.346

29 Fuglsang J, Skjaerbaek C, Frystyk J, Flyvbjerg A, Ovesen P. A longitudinal study of serum adiponectin during normal pregnancy. BJOG. 2006;113(01):110-113. Doi: 10.1111/j.14710528.2005.00792.x

30 Gueuvoghlanian-Silva BY, Torloni MR, Mattar R, Oliveira LS, Scomparini FB, Nakamura MU, et al. Profile of inflammatory mediators in gestational diabetes mellitus: phenotype and genotype. Am J Reprod Immunol. 2012;67(03):241-250. Doi: 10.1111/ j.1600-0897.2011.01090.x

31 Mazaki-Tovi S, Kanety H, Pariente C, Hemi R, Wiser A, Schiff E, et al. Maternal serum adiponectin levels during human pregnancy. J Perinatol. 2007;27(02):77-81. Doi: 10.1038/sj.jp.7211639

32 Kajantie E, Kaaja R, Ylikorkala O, Andersson S, Laivuori H. Adiponectin concentrations in maternal serum: elevated in preeclampsia but unrelated to insulin sensitivity. J Soc Gynecol Investig. 2005;12(06):433-439. Doi: 10.1016/j.jsgi.2005.04.006

33 Briana DD, Malamitsi-Puchner A. The role of adipocytokines in fetal growth. Ann N Y Acad Sci. 2010;1205:82-87. Doi: 10.1111/ j.1749-6632.2010.05650.x

34 Mazaki-Tovi S, Romero R, Vaisbuch E, Erez O, Mittal P, Chaiworapongsa $\mathrm{T}$, et al. Maternal serum adiponectin multimers in patients with a small-for-gestational-age newborn. J Perinat Med. 2009;37(06):623-635. Doi: 10.1515/JPM.2009.128

35 Zhang ZQ Lu QG, Huang J, Jiao CY, Huang SM, Mao LM. Maternal and cord blood adiponectin levels in relation to post-natal body size in infants in the first year of life: a prospective study. BMC Pregnancy Childbirth. 2016;16(01):189. Doi: 10.1186/s12884016-0978-9

36 Dawczynski K, de Vries H, Beck JF, Schleußner E, Wittig S, Proquitté $\mathrm{H}$ Adiponectin serum concentrations in newborn at delivery appear to be of fetal origin. J Pediatr Endocrinol Metab. 2014;27(3-4):273-278. Doi: 10.1515/jpem-2013-0218

37 Aye IL, Powell TL, Jansson T. Review: Adiponectin-the missing link between maternal adiposity, placental transport and fetal growth? Placenta. 2013;34(Suppl):S40-S45. Doi: 10.1016/j.placenta.2012.11.024 